$\left[\begin{array}{llll}\text { 衛 } & \text { 生 } & \text { 伦 } & \text { 学 } \\ \multicolumn{35}{c}{\text { (5) }} & 339-346 & \text { KAGAKU } & (1989)\end{array}\right]$

薄層等電点電気泳動法の食品分析への応用（第 3 報）等電点電気泳動

パターンの数值化によるキノコ種の判別とクサウラベニタケ

食中毒事例への応用

\author{
浮島美之, ${ }^{a}$ 秋元宣子, ${ }^{b}$ 成田弘子, ${ }^{b}$ 石川雅章, ${ }^{a}$ \\ 藤井貴野, ${ }^{a}$ 木野正彦, ${ }^{a}$ 山脇正樹, ${ }^{a}$ \\ 岡田昌二 $c$ \\ 静岡県沼津保健所, ${ }^{a}$ 静岡県衛生環境センター, ${ }^{b}$ 静岡県立大学薬学部 $c$
}

\title{
Studies on the Application of Thin Layer Isoelectric Focusing to Food Analysis. III. Identification of Mushroom by Numerical Value of Isoelectric Focusing Pattern and Application to Food Poisoning by Rhodophyllus rhodopolius
}

\author{
Yoshiyuki Ukishima, ${ }^{a}$ Noriko Akimoto, ${ }^{b}$ Hiroko Narita, ${ }^{b}$ \\ Masaaki IshiKawa, ${ }^{a}$ Yoshino Fujil, ${ }^{a}$ Masahiko Kino, ${ }^{a}$ \\ MASAKI YAMAWAKI $^{a}$ and ShOJI OKaDA ${ }^{c}$
}

Shizuoka Prefectural Numazu Health Center, ${ }^{a}$ 1.3 Takashimahoncho, Numazu 410,

Japan, Shizuoka Prefectural Institute of Public Health and Environmental Science, ${ }^{b}$ 4-27-2 Kita-ando, Shizuoka 420, Japan and University of Shizuoka School of

Pharmaceutical Sciences, ${ }^{c} 395$ Yada, Shizuoka 422, Japan

(Received May 9, 1989)

To identify the species of mushrooms mainly for the distinction of poisonous mushrooms from edible ones, thin layer isoelectric focusing analysis was applied on their water-soluble proteins.

1. The electrophoretic profiles were species-specific. The proteins extracted from the cap and stem in a species gave essentially identical profiles.

2. The profiles of cap proteins of 10 individuals of Akamomitake (Lactarius deliciosus) were indifferent, indicating that the intra-species variation of water-soluble proteins was little.

3. The heat treatment at higher than $60{ }^{\circ} \mathrm{C}$, for $10 \mathrm{~min}$, of the water-soluble proteins of Dokutsurutake (Amanita virosa) caused temperature-dependent disappearance of protein bands, while not significant change up to $60{ }^{\circ} \mathrm{C}$.

4. The values of $\mathrm{pI}$ and relative peak height of isoelectro-focused water-soluble protein bands were numerically expressed. These numerical values were species-specific, indicating that mushroom species might be identified by analyzing the water-soluble proteins with a verification of the tables of these numerical values.

5. The present method was applied for the identification of poisonous Kusaurabenitake (Rhodophyllus rhodopolius) mixed in Urabenihoteishimeji (Rhodophyllus crassipes) which caused a food poisoning incident. The former mushroom was satisfactorily identified by this method.

Keywords — isoelectric focusing; water-soluble protein; numerical value; speciesspecific identification; mushroom-species ; poisonous mushroom; food poisoning; Rhodophyllus rhodopolius; Rhodophyllus crassipes 


\section{緒言}

キノコは分類上担子菌類と子囊菌類に属し，大部 分のキノコは担子菌類に属する。乩キノコ種の判別

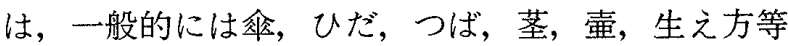

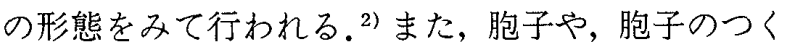
細胞の形，更にキノコに含まれる成分，呈色反応等 によっても判別が行方れる。.314) キコは日本には約 5000 種類あるといわれているが，そのうち和名のつ いたキノコは約 1500 種で，そのなかで食べられるキ ノコはせいぜい 200 種である。一方毒キノコは 30 種 以上ある. ${ }^{5)}$

キノコを食用に供する場合，外形の良く似たキノ コを的確に判別することは難しく，毎年 500 人ほど が中毒を起こし，数名の死者がでている。,7)キノコ による食中毒が発生した場合，残存しているキノコ が少なかったり，外部形態を留めていないとその食 中毒原因調查は困難となり，中毒患者に対する適切 な処置もとりにくい.

我々はこれまでに水溶性筋形質蛋白質を使用した 電気泳動法による魚種判別法について，食品衛生学 的に検討してきた。 ${ }^{8-10)}$ 今回このなかの等電点電気 泳動法をキノコ種の判別に応用したところ，キノコ の水溶性蛋白質の等電点電気泳動パターンに種特異 性が認められ，またその泳動パターンを数值化して キノコ種の判別に適用することが可能であることを 見いだした．また，沼津市大平山において採取され たクサウラベニタケによる食中毒事例に本法を応用 したところ，明確な種判別ができたので併せて報告 する。

\section{実 験 方 法}

1. 試料 Table I に示した同担子菌亜綱 (Homobasid-iae）に属するキノコを実験に用いた。 このうちクサウラベニタケ (Rhodophyllus rhodopolius）及びウラベニホテイシメジ（Rhodophyllus crassipes）は沼津市大平山で採取され食中毒 事例に関与したもので，その他のキノコは富士山麓 周辺で採取されたものである。試料のキノコはー $20^{\circ}$ C 以下で冷凍保存し実験に供した。

2. 試薬アンフォラインプレート：LKB 社 製，ポリアクリルアミド $5 \%$ ，両性担体としてアン フォライン $2.5 \%$ 含むアンフォライン $\mathrm{PAG} 7^{\circ}$ レート, $\mathrm{pH} 3.5-9.5,1 \mathrm{~mm} \times 22.6 \mathrm{~cm} \times 9.5 \mathrm{~cm}$.

$\mathrm{pI}$ マーカー：等電点 $(\mathrm{pI})$ が既知である標準蛋白 質を 11 種類混合したPharmacia 社製カリブレー
ションキット $(\mathrm{pH} 3-10)$ のバイアルに, $100 \mu \mathrm{l}$ の 蒸留水を加之蛋白質を溶解した。

脱色液： $50 \%(\mathrm{v} / \mathrm{v})$ エ夕ノール水溶液と $16 \%(\mathrm{v} /$ v）酢酸溶液を用時等量混合した。

固定液：スルホサリチル酸 $17.3 \mathrm{~g}$ とトリクロロ 酢酸 $57.5 \mathrm{~g}$ に水を加えて溶解し $500 \mathrm{ml}$ とした。 染色液：Coomassie brilliant blue R250 $0.46 \mathrm{~g}$ を脱 色液 $400 \mathrm{ml}$ に溶解した。

保存液：脱色液にグリセリンを加えて $10 \%(\mathrm{v} / \mathrm{v})$ 溶液とした。

グアヤクチンキ溶液：グアヤク脂 $1 \mathrm{~g}$ に $70 \%$ 工 タノール $5 \mathrm{ml}$ を加之, 擋找溶解した。

硫酸バニリン溶液：水 $3 \mathrm{ml}$ に濃硫酸 $8 \mathrm{ml}$ を加 え，それにバニリン $1 \mathrm{~g}$ を溶解した。

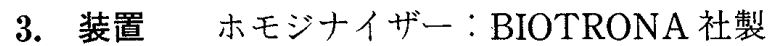
バイオトロン BT $250 \mathrm{SM}$ 型。

電気泳動装置：LKB 社製定電力電源装置マクロ ドライブ 5 型に，同社製等電点電気泳動装置マルチ フォーII 型を接続して使用した。

デンシトメーター：島津製作所製 2 波長クロマト スキャナCS-910 型。

4. 実験操作 1 ) 水溶性蛋白質の抽出— 細 切したキノコの傘又は茎 $1 \mathrm{~g}$ に水 $1 \mathrm{ml}$ を加えてバ イオトロンを用いてホモジナイズし， $2{ }^{\circ} \mathrm{C}$ に冷却し て, $16000 \mathrm{rpm}$ で 20 分間遠心分離して得た上澄液を 水溶性蛋白質の試験溶液とした。

2 ) 電気泳動— $7{ }^{\circ} \mathrm{C}$ の冷却水を循環させた電 気泳動装置に，アンフォラインプレートをセットし て $5 \times 10 \mathrm{~mm}$ のろ紙片をプレートの中央に置き，試 験溶液及U゙ $\mathrm{pI}$ マーカー $10 \mu 1$ をマイクロピペットを 用いてろ紙に塗布した。陽極に $1 \mathrm{~m}$ 燐酸溶液, 陰極 に $1 \mathrm{~N}$ 水酸化ナトリウム溶液を含ませたろ紙を置 き, 通電は定電力 $30 \mathrm{~W}$ (最高電圧 $1500 \mathrm{~V}$, 最高電流 $40 \mathrm{~mA}$ ) で行い，30 分後にろ紙片を取り除き，更に 60 分間泳動した。

3 ) 蛋白質固定及び染色—プレートを固定液に 45 分間, 次に脱色液に 20 分間, $60^{\circ} \mathrm{C}$ に加温した染色 液に 10 分間順次浸した。更に脱色液に 1 夜浸した後 保存液に 60 分間浸した。次にプレートを $50^{\circ} \mathrm{C} て ゙ ~ 40$ 分間乾燥し，ゲルの表面にセロファンシートを密着 させて保存プレートとした。

4) デンシトメトリー及び蛋白質バンドの数值化 一一保存プレートを用いて, pI マーカーとキノコ類 の水溶性蛋白質の等電点電気泳動パターンを， 2 波 長クロマトスキャナを使用して試料側 $595 \mathrm{~nm}$, 対照 側 $700 \mathrm{~nm}$ の 2 波長でデンシトメトリーを行った. 
TABle I. Japanese and Scientific Names of the Mushroom Species Examined

\begin{tabular}{|c|c|c|c|}
\hline Sample No. & Japanese name & Scientific name & Family \\
\hline 1 & Kakishimeji & Tricholoma ustale & Tricholomataceae \\
\hline 2 & Samatsumodoki & Tricholomopsis rutilans & Tricholomataceae \\
\hline 3 & Kunugitake & Mycena galericulata & Tricholomataceae \\
\hline 4 & Sakuratake & Mycena pura & Tricholomataceae \\
\hline 5 & Chishiotake & Mycena haematopus & Tricholomataceae \\
\hline 6 & Naratake & Armillariella mellea & Tricholomataceae \\
\hline 7 & Sugihiratake & Pleurocybella porrigens & Tricholomataceae \\
\hline 8 & Hoteishimeji & Clitocybe clavipes & Tricholomataceae \\
\hline 9 & Kayatake & Clitocybe infundibuliformis & Tricholomataceae \\
\hline 10 & Tsukiyotake & Lampteromyces japonicus & Tricholomataceae \\
\hline 11 & Mukitake & Hohenbuehelia serotina & Tricholomataceae \\
\hline 12 & Shiitake & Lentinus edodes & Tricholomataceae \\
\hline 13 & Dokutsurutake & Amanita virosa & Amanitaceae \\
\hline 14 & Tamagotengutake & Amanita phallodes & Amanitaceae \\
\hline 15 & Tamagotake & Amanita caesarea & Amanitaceae \\
\hline 16 & Watakarakasatake & Lepiota clypeolaria & Agaricaceae \\
\hline 17 & Hitoyotake & Coprinus atramentarius & Coprinaceae \\
\hline 18 & Nigakuritake & Naematoloma fasciculare & Strophariaceae \\
\hline 19 & Tyanametsumutake & Pholiota lubrica & Strophariaceae \\
\hline 20 & Numerisugitakemodoki & Pholiota aurivella & Strophariaceae \\
\hline 21 & Moegitake & Stropharia aeruginosa & Strophariaceae \\
\hline 22 & Kokintake & Cortinarius croceoconus & Cortinariaceae \\
\hline 23 & Fujiirotakemodoki & Cortinarius variicolor & Cortinariaceae \\
\hline 24 & Ookinuhadatoyamatake & Inocybe fastigiata & Cortinariaceae \\
\hline 25 & Kusaurabenitake & Rhodophyllus rhodopolius & Rhodophyllaceae \\
\hline 26 & Urabenihoteishimeji & Rhodophyllus crassipes & Rhodophyllaceae \\
\hline 27 & Akamomitake & Lactarius deliciosus & Russulaceae \\
\hline 28 & Kihatsudake & Lactarius flavidulus & Russulaceae \\
\hline 29 & Tsuchikaburi & Lactarius piperatus & Russulaceae \\
\hline 30 & Dokubenitake & Russulaceae emetica & Russulaceae \\
\hline 31 & Yaburebenitake & Russulaceae lepida & Russulaceae \\
\hline 32 & Usutake & Cantharellus floccosus & Cantharellaceae \\
\hline 33 & Kanoshita & Hydnum repandum & Hydnaceae sensu lato \\
\hline 34 & Bunaharitake & Creolophus spathulatus & Hydnaceae sensu lato \\
\hline 35 & Ashigurotake & Polyporellus picipes & Polyporaceae \\
\hline 36 & Hokoritake & Lycoperdon gemmatum & \\
\hline
\end{tabular}

$1,2,10,14,18$ and $25:$ poisonous mushrooms.

Fig. 1 に示す pI マーカーのデンシトメトリーの チャートにより，Fig. 2 に示す泳動プレートの pH 勾配のカーブを作製した。これを標準として各キノ コ種の蛋白質バンドのなかより，普遍的に存在する 比較的大きなピーク及びそのキノコに特徵的なピー クを $5-10$ 本程度選定し, 等電点 $(\mathrm{p} I)$ 及びピーク の高さの比率 (R.P.H. ; relative peak height) を数 值化した。

\section{実験結果及び考察}

\section{1. 子実体の部位による泳動パターンの差異}

食中毒事例等でキノコの種判別が必要になった場 合，未調理で残存しているものが原形を留めていな かったり，荎部分のみであることも考えられる。そ こで釷と茥の泳動パターンの差をドクツルタケ，力 キシメジ及びニガクリタケの 3 種類の毒キノコを用 いて比較した結果を Fig. 3 に示す.なお, pI 6.25 付 近にみられる蛋白質バンドようのものは，乃紙片を ゲル上において電気泳動した際，酸性側にできたゲ 


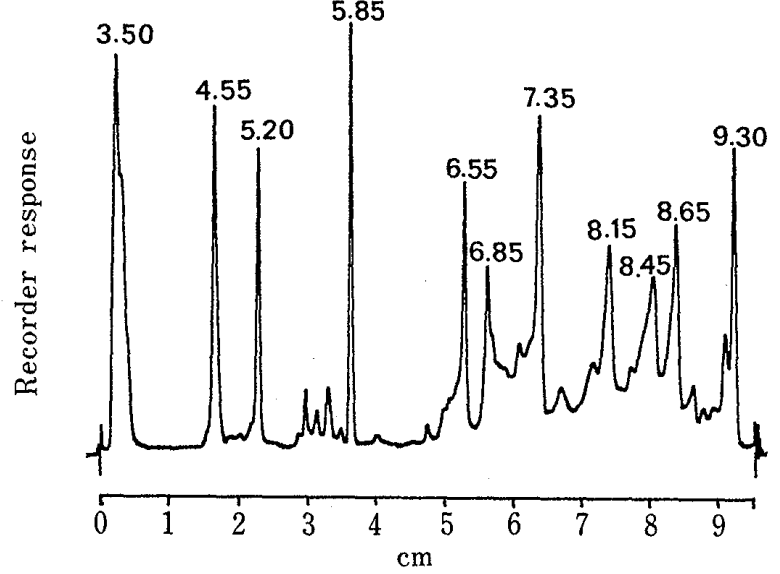

Fig. 1. Densitometric Pattern of Isoelectric Focusing of pI Marker

Numbers above peaks indicate pI values.

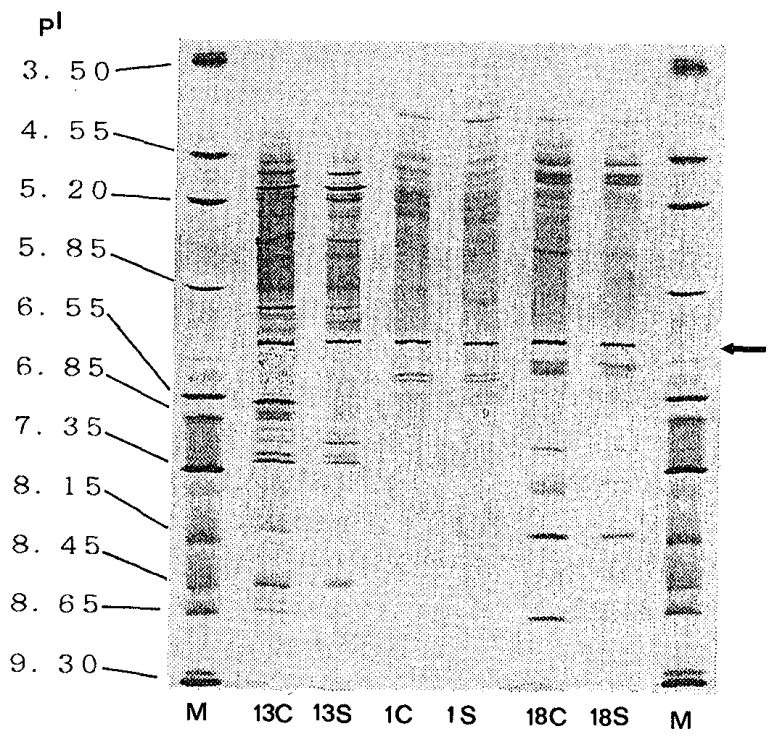

Fig. 3. Isoelectric Focusing Patterns of Water Soluble Proteins from Caps and Stems of Mushrooms

$\mathrm{M}$ : pI marker.

13C: cap of Dokutsurutake, 13S : stem of Dokutsurutake, 1C : cap of Kakishimeji, 1S : stem of Kakishimeji, 18C : cap of Nigakuritake, $18 \mathrm{~S}$ : stem of Nigakuritake.

The band-like lines indicated with an arrow are the artifacts described in the text.

ルの傷であり，以後のデーターも含めて判定から除 いた． 3 種の毒キノコの泳動パターンには，明確な 種特異性が認められた。それぞれのキ/コの傘部分 と茎部分を比較すると，ドクツルタケとニガクリタ ケにおいては，茎の蛋白質バンドが金にくらべてう すくなるものが若干認められたほかは，同等な泳動 パターンであった。カキシメジでは，傘と荃の泳動

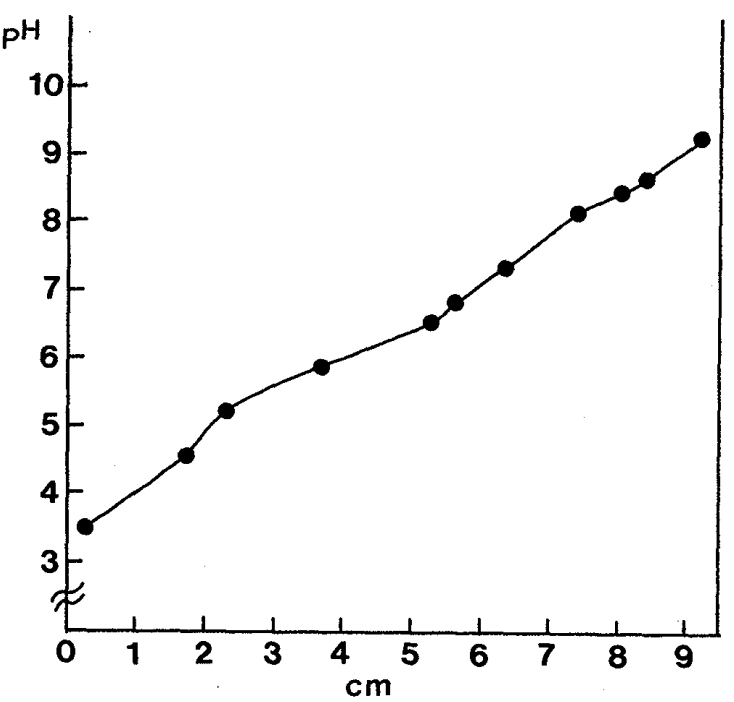

Fig. 2. pH Gradient of Polyacrylamide Gel

パターンに差はみられなかった。

以上の結果より，傘と荃の泳動パターンを比較す ると荃で一部の蛋白質バンドがうすくなるキノコ種 があるが,他の蛋白質バンドを比較することにより， キノコ種の判別は可能であった。

\section{2. 同一種内における泳動パターンの差異}

キノコ種の判別のためには等電点電気泳動パター ンにおける種内変異の有無の確認が必要である。そ こで富士山麓周辺にて採取された約 200 個体のアカ モミタケをモデルに選び，それより 10 個体を無作為 に抽出し，その金部分を用いて，水溶性蛋白質の等 電点電気泳動パターンを調べた結果を Fig. 4 に示 す.アカモミタケの泳動パターンは, pI 4.5-6.5の 範囲でそれぞれの蛋白質バンドがすべての個体で共 通にみられた、これらの蛋白質バンドを使用するこ とによりアカモミタケの判別は十分可能であった。

3. 水溶性蛋白質の加熱变性による等電点電気泳 動パターンの変化

ドクツルタケの金部分の水溶性蛋白質抽出液を, $30 ， 40 ， 50 ， 60 ， 70 ， 80 ， 90$ 及び $100^{\circ} \mathrm{C}$ にそれぞれ 10 分間放置し，泳動パターンの変化を調べた結果を Fig. 5 に示す，蛋白質バンドは， $60^{\circ} \mathrm{C}$ を超す加熱処 理により急激に減少し, $80^{\circ} \mathrm{C}$ 以上では $\mathrm{pI} 4.75$ 及び 5.10 の薄い蛋白質バンドしか残存しなかった。

\section{4. 水溶性蛋白質の等電点電気泳動パターンの数} 值化

富士山麓周辺等にて採取し凍結保存したキノコ 36 種の傘部分より抽出した水溶性蛋白質の等電点 電気泳動より得られた主な蛋白質バンドについて, pI と R.P.H.を数值化した結果を Table II に示す。 


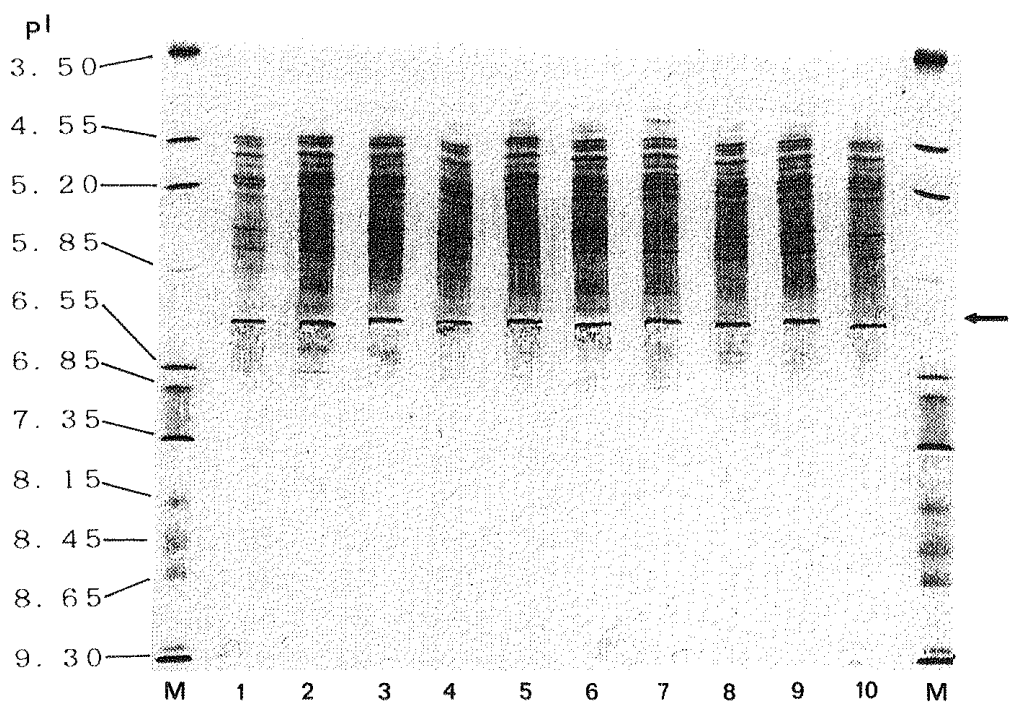

Fig. 4. Comparison of Intra-Species Difference of Isoelectric Focusing Patterns of Water-Soluble Proteins from 10 Akamomitakes

$\mathrm{M}: \mathrm{pl}$ marker.

1-10: Akamomitake.

The band-like lines indicated with an arrow are the artifacts described in the text.

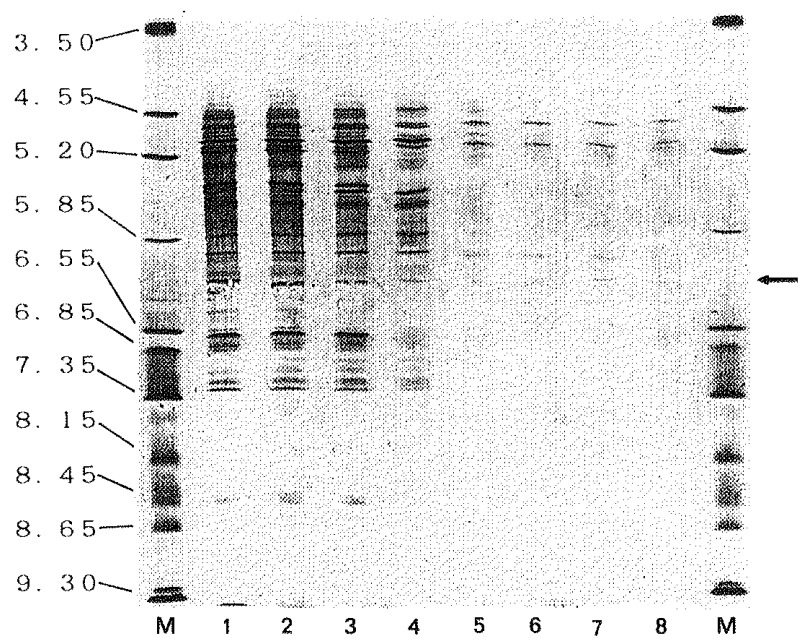

Fig. 5. Isoelectric Focusing Patterns of WaterSoluble Proteins after Heating

Mushroom species: Dokutsurutake.

Heating condition: $1 \quad 30^{\circ} \mathrm{C}, 2 \quad 40^{\circ} \mathrm{C}, 3 \quad 50^{\circ} \mathrm{C}, 4 \quad 60^{\circ} \mathrm{C}, 5$ $70{ }^{\circ} \mathrm{C}, 6 \quad 80^{\circ} \mathrm{C}, 7 \quad 90^{\circ} \mathrm{C}$ and $8 \quad 100^{\circ} \mathrm{C}$, for $10 \mathrm{~min}$.

$\mathrm{M}$ : pI marker.

The band-like lines indicated with an arrow are the artifacts described in the text.

なお数值化を行う際，ゲル上についたろ紙片の傷に よる $\mathrm{pI} 6.25$ 付近の蛋白質バンド様のものは数值化 操作から除外した。キノコでは全般的に弱酸性部分
に出現する蛋白質バンドが多かったが，それぞれの キノコ種の違いにより各蛋白質バンドのピークの pI 及U゙ R.P.H.に特異性が認められ, Table II の数值 化表を使用したキノコ種の判別が可能であった。 な お本数值化表によりキノコ種の検索を行う場合， R. P.H.が 100 ないし 100 に近い漕い蛋白質バンドの $\mathrm{pI}$ が合致するものを探し，その後薄い蛋白質バンド の $\mathrm{pI}$ が合うことを確認するのが便利であった.また 今後キノコによる食中毒が発生した場合，キノコが 比較的鮮度の上い状態で残存し，本数值化表にある キノコ種であれば，食中毒原因キノコの水溶性蛋白 質の等電点電気泳動パターンを数值化することによ り，標準となるキノコを手元に保存してない場合で あっても，本数值化表を検索することによりその種 判別は可能と思われる。本法は形態学的鑑定ととも に，その種判別の一手法として役立つものと期待さ れる。

5. クサウラベニタケによる食中帮掌例への本法 の応用

1987 年 10 月 8 日, 沼津市大平山にて採取した イッポンシメジ属のウラベニホテイシメジと思われ るキノコを撕食した 2 名が, 30 分後激しい嘔吐, 下 梸, 腹痛等の胃腸障害を起こし，毒キノコによる食 中毒と診断されたので，そのキノコ種の鑑別に本法 
TABLE II . Numerical Values of Isoelectric Focusing Patterns of Water-Soluble Proteins from 36 Mushroom Species on pH Gradient (3.5-9.5) Polyacrylamide Gel

\begin{tabular}{|c|c|c|c|c|c|c|c|c|c|c|c|c|c|}
\hline \multirow{2}{*}{$\begin{array}{c}\text { Sample } \\
\text { No. }\end{array}$} & \multirow{2}{*}{$\begin{array}{l}\text { Japanese name of } \\
\text { mushroom species } \\
\text { Kakishimeji }\end{array}$} & \multicolumn{12}{|c|}{ Numerical values of isoelectric focusing patterns } \\
\hline & & $\mathrm{pI}$ & 4.10 & 4.55 & 4.75 & 5.10 & 5.15 & 5.30 & 6.35 & 6.40 & & & \\
\hline & & R.P.H. & 23 & 46 & 46 & 100 & 96 & 81 & 27 & 23 & & & \\
\hline \multirow[t]{2}{*}{2} & Samatsumodoki & $\mathrm{pI}$ & 4.65 & 4.80 & 4.85 & 5.15 & 5.40 & 5.50 & 5.70 & & & & \\
\hline & & R.P.H. & 77 & 57 & 60 & 100 & 57 & 37 & 20 & & & & \\
\hline \multirow[t]{2}{*}{3} & Kunugitake & $\mathrm{pI}$ & 3.95 & 4.05 & 4.30 & 4.40 & 4.60 & 4.75 & 4.90 & 5.00 & 5.50 & 5.85 & \\
\hline & & R.P.H. & 100 & 47 & 17 & 53 & 30 & 35 & 37 & 88 & 28 & 16 & \\
\hline \multirow[t]{2}{*}{4} & Sakuratake & $\mathrm{pI}$ & 4.40 & 4.45 & 4.50 & 4.65 & 4.75 & 4.90 & 5.10 & 5.65 & 7.00 & & \\
\hline & & R.P.H. & 24 & 47 & 10 & 58 & 15 & 14 & 24 & 10 & 100 & & \\
\hline \multirow[t]{2}{*}{5} & Chishiotake & pI & 4.55 & 4.60 & 4.80 & 5.05 & 5.20 & 5.30 & 5.50 & & & & \\
\hline & & R.P.H. & 50 & 59 & 29 & 100 & 41 & 24 & 26 & & & & \\
\hline \multirow[t]{2}{*}{6} & Naratake & $\mathrm{pI}$ & 4.15 & 4.35 & 4.60 & 4.80 & 5.00 & 5.60 & 9.25 & & & & \\
\hline & & R.P.H. & 100 & 28 & 39 & 22 & 67 & 72 & 28 & & & & \\
\hline \multirow[t]{2}{*}{7} & Sugihiratake & $\mathrm{pI}$ & 4.50 & 4.70 & 4.80 & 5.15 & 5.25 & 5.35 & 5.45 & 5.70 & 5.90 & 5.95 & 6.10 \\
\hline & & R.P.H. & 100 & 15 & 12 & 20 & 18 & 12 & 12 & 12 & 11 & 12 & 64 \\
\hline \multirow[t]{2}{*}{8} & Hoteishimeji & $\mathrm{pI}$ & 4.55 & 4.70 & 4.85 & 5.00 & 5.05 & 5.25 & 5.40 & 5.60 & 5.65 & 6.30 & \\
\hline & & R.P.H. & 45 & 100 & 39 & 68 & 80 & 45 & 66 & 48 & 41 & 48 & \\
\hline \multirow[t]{2}{*}{9} & Kayatake & pI & 4.35 & 4.55 & 4.75 & 5.50 & 6.30 & 6.35 & 6.50 & 9.15 & & & \\
\hline & & R.P.H. & 30 & 100 & 26 & 18 & 33 & 35 & 15 & 26 & & & \\
\hline \multirow[t]{2}{*}{10} & Tsukiyotake & $\mathrm{pI}$ & 3.50 & 3.70 & 4.85 & 4.95 & 5.15 & 5.45 & 5.75 & 7.70 & & & \\
\hline & & R.P.H. & 55 & 100 & 38 & 41 & 71 & 47 & 64 & 17 & & & \\
\hline \multirow[t]{2}{*}{11} & Mukitake & $\mathrm{pI}$ & 4.30 & 4.50 & 4.85 & 4.90 & 5.15 & & & & & & \\
\hline & & R.P.H. & 77 & 54 & 77 & 77 & 100 & & & & & & \\
\hline \multirow[t]{2}{*}{12} & Shiitake & $\mathrm{pI}$ & 3.50 & 4.45 & 4.90 & 5.20 & 6.90 & & & & & & \\
\hline & & R.P.H. & 22 & 100 & 16 & 24 & 36 & & & & & & \\
\hline \multirow[t]{2}{*}{13} & Dokutsurutake & $\mathrm{pI}$ & 4.75 & 4.90 & 5.45 & 5.60 & 5.80 & 5.95 & 6.50 & 6.65 & 6.75 & 9.35 & \\
\hline & & R.P.H. & 25 & 100 & 37 & 16 & 20 & 17 & 45 & 21 & 28 & 21 & \\
\hline \multirow[t]{2}{*}{14} & Tamagotengutake & $\mathrm{pI}$ & 4.50 & 4.60 & 5.00 & 5.20 & 5.55 & 5.95 & 6.55 & 7.15 & 7.20 & 8.45 & 8.65 \\
\hline & & R.P.H. & 16 & 34 & 70 & 34 & 74 & 20 & 100 & 37 & 29 & 22 & 16 \\
\hline 15 & Tamagotake & $\mathrm{pI}$ & 4.35 & 4.55 & 4.70 & 5.10 & 5.30 & & & & & & \\
\hline & & R.P.H. & 69 & 100 & 68 & 60 & 41 & & & & & & \\
\hline 16 & Watakarakasatake & $\mathrm{pI}$ & 4.60 & 4.75 & 4.80 & 4.90 & 5.25 & 5.50 & 5.55 & 5.60 & 5.90 & 7.85 & \\
\hline & & R.P.H. & 64 & 50 & 50 & 39 & 82 & 75 & 36 & 39 & 100 & 86 & \\
\hline 17 & Hitoyotake & $\mathrm{pI}$ & 3.80 & 4.25 & 4.75 & 5.20 & 5.65 & & & & & & \\
\hline & & R.P.H. & 14 & 12 & 100 & 24 & 36 & & & & & & \\
\hline 18 & Nigakuritake & $\mathrm{pI}$ & 4.65 & 4.80 & 4.90 & 5.60 & 6.40 & 8.15 & 8.70 & & & & \\
\hline & & R.P.H. & 56 & 67 & 100 & 41 & 37 & 48 & 26 & & & & \\
\hline 19 & $\begin{array}{l}\text { Tyanametsumuta- } \\
\text { ke }\end{array}$ & $\mathrm{pI}$ & 5.15 & 5.20 & 5.35 & 5.70 & 7.20 & & & & & & \\
\hline & & R.P.H. & 100 & 85 & 64 & 44 & 44 & & & & & & \\
\hline 20 & Numerisugitakemodoki & $\mathrm{pI}$ & 4.65 & 4.80 & 5.25 & 5.30 & 5.65 & 7.25 & & . & & & \\
\hline & & R.P.H. & 18 & 31 & 13 & 21 & 100 & 40 & & & & & \\
\hline 21 & Moegitake & $\mathrm{pI}$ & 4.75 & 5.15 & 5.30 & & & & & & & & \\
\hline & & R.P.H. & 100 & 53 & 28 & & & & & & & & \\
\hline 22 & Kokintake & $\mathrm{pI}$ & 4.10 & 4.50 & 4.60 & 4.85 & 5.15 & 5.25 & 5.60 & 5.75 & & & \\
\hline & & R.P.H. & 29 & 5 & 7 & 20 & 100 & 9 & 8 & 49 & & & \\
\hline 23 & Fujiirotakemodoki & $\mathrm{pI}$ & 4.60 & 4.80 & 4.85 & 5.10 & 5.20 & 5.30 & 5.60 & 6.20 & 6.50 & & \\
\hline & & R.P.H. & 100 & 91 & 68 & 45 & 50 & 27 & 25 & 25 & 23 & & \\
\hline 24 & Ookinuhadatoyamatake & $\mathrm{pI}$ & 4.60 & 4.75 & 5.05 & 5.25 & 5.55 & 5.60 & 5.65 & 5.80 & 6.05 & 6.85 & \\
\hline & & R.P.H. & 80 & 90 & 75 & 45 & 85 & 100 & 70 & 45 & 45 & 20 & \\
\hline 25 & Kusaurabenitake & $\mathrm{pI}$ & 3.80 & 4.75 & 4.95 & 5.20 & 5.30 & 5.40 & 8.65 & 9.00 & & & \\
\hline & & R.P.H. & 56 & 44 & 100 & 88 & 52 & 64 & 48 & 20 & & & \\
\hline 26 & Urabenihoteishimeji & $\mathrm{pI}$ & 4.60 & 5.85 & 5.15 & 5.50 & 5.60 & 5.85 & 5.95 & & & & \\
\hline & & R.P.H. & 35 & 38 & 100 & 31 & 46 & 38 & 27 & & & & \\
\hline
\end{tabular}




\begin{tabular}{|c|c|c|c|c|c|c|c|c|c|c|c|c|c|}
\hline \multirow[t]{2}{*}{27} & Akamomitake & $\mathrm{pI}$ & 4.50 & 4.55 & 4.75 & 4.90 & 5.10 & 5.20 & 5.30 & 5.55 & 5.70 & 6.60 & \\
\hline & & R.P.H. & 92 & 80 & 88 & 28 & 68 & 76 & 40 & 100 & 52 & 56 & \\
\hline \multirow[t]{2}{*}{28} & Kihatsudake & $\mathrm{pI}$ & 4.55 & 4.70 & 5.10 & 5.50 & 6.85 & & & & & & \\
\hline & & R.P.H. & 100 & 12 & 79 & 13 & 10 & & & & & & \\
\hline \multirow[t]{2}{*}{29} & Tsuchikaburi & $\mathrm{pI}$ & 4.15 & 4.25 & 4.30 & 4.45 & 4.70 & 4.85 & 4.95 & 8.70 & 8.85 & & \\
\hline & & R.P.H. & 17 & 5 & 100 & 38 & 4 & 11 & 13 & 5 & 4 & & \\
\hline \multirow[t]{2}{*}{30} & Dokubenitake & $\mathrm{pI}$ & 4.80 & 5.70 & 5.85 & 6.05 & 6.10 & 7.60 & & & & & \\
\hline & & R.P.H. & 75 & 100 & 44 & 25 & 31 & 25 & & & & & \\
\hline \multirow[t]{2}{*}{31} & Yaburebenitake & pI & 4.35 & 4.65 & 4.80 & 5.15 & 5.35 & 5.50 & 5.55 & 7.05 & 7.20 & & \\
\hline & & R.P.H. & 27 & 25 & 100 & 20 & 30 & 63 & 87 & 37 & 22 & & \\
\hline \multirow[t]{2}{*}{32} & Usutake & $\mathrm{pI}$ & 4.20 & 4.50 & 4.65 & 4.80 & 5.00 & 9.30 & & & & & \\
\hline & & R.P.H. & 21 & 100 & 42 & 26 & 21 & 42 & & & & & \\
\hline \multirow[t]{2}{*}{33} & Kanoshita & pI & 3.55 & 4.65 & 5.10 & 9.35 & & & & & & & \\
\hline & & R.P.H. & 100 & 83 & 92 & 33 & & & & & & & \\
\hline \multirow[t]{2}{*}{34} & Bunaharitake & $\mathrm{pI}$ & 4.10 & 4.25 & 4.55 & 4.75 & & & & & & & \\
\hline & & R.P.H. & 30 & 34 & 100 & 72 & & & & & & & \\
\hline \multirow[t]{2}{*}{35} & Ashigurotake & $\mathrm{pI}$ & 4.60 & 4.85 & 5.05 & 5.25 & 5.55 & & & & & & \\
\hline & & R.P.H. & 30 & 100 & 30 & 20 & 20 & & & & & & \\
\hline \multirow[t]{2}{*}{36} & Hokoritake & $\mathrm{pl}$ & 3.55 & 4.35 & 4.55 & 4.80 & 5.05 & 5.15 & 5.30 & 5.50 & 5.55 & 5.60 & 9.40 \\
\hline & & R.P.H. & 10 & 16 & 47 & 44 & 81 & 100 & 47 & 58 & 70 & 47 & 12 \\
\hline
\end{tabular}

Sample numbers correspond those in TABLE I .

R.P.H. : relative peak height (maximum peak height $=100$ )
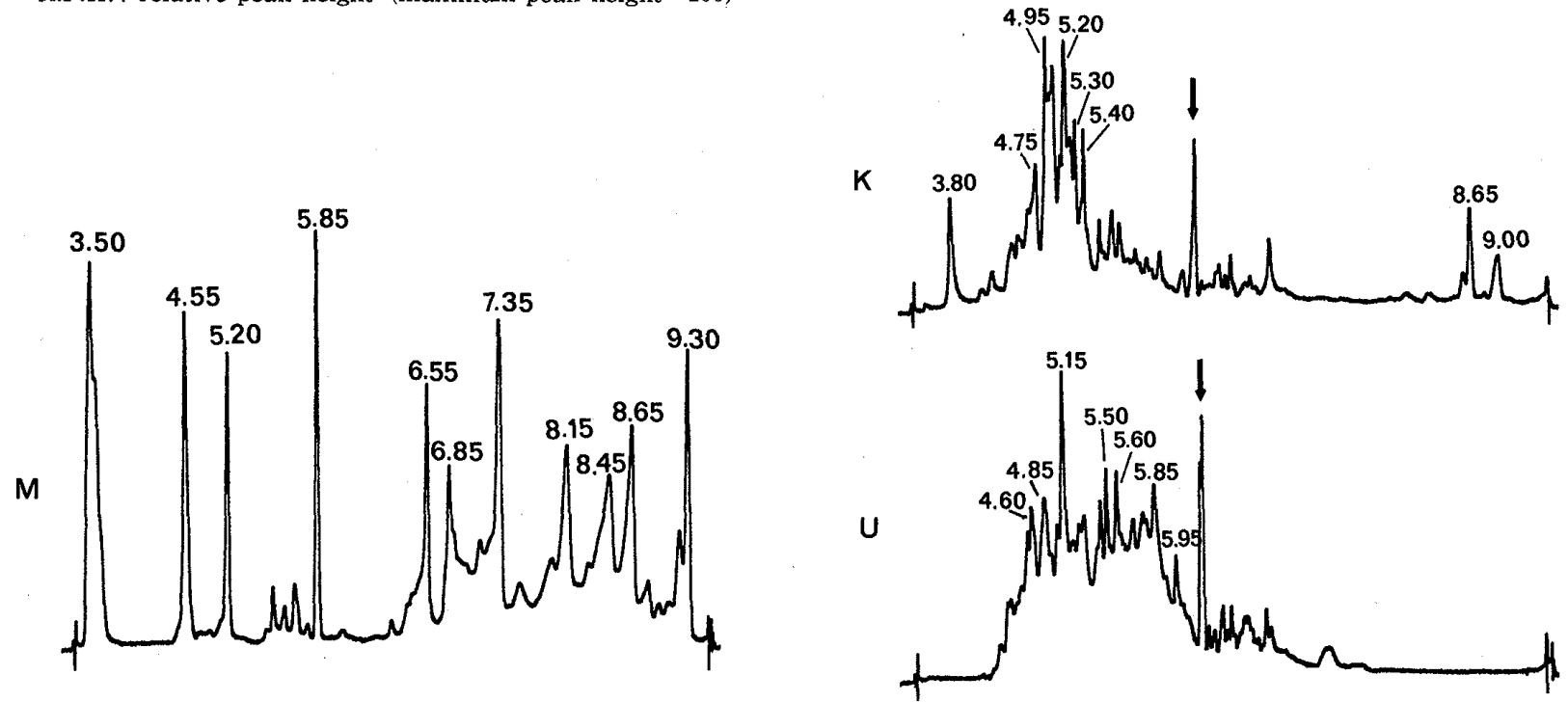

Fig. 6. Densitometric Patterns of Isoelectric Focusing of Water-Soluble Proteins from Kusaurabenitake and Urabenihoteishimeji

$\mathrm{M}: \mathrm{pI}$ marker.

$\mathrm{K}$ : Kusaurabenitake.

U: Urabenihoteishimeji.

Numbers above peaks indicate $\mathrm{pI}$ values.

The peaks indicated with an arrow are the artifacts described in the text.

の応用を試みた。

等電点電気泳動分析に先だって, まず形態学的調 查を行った。食中毒患者宅に残存していた未調理の キノコを外部形態により調べたところ，大半がウラ ベニホテイシメジであったが，非常によく似た同属 のクサウラベニタケと思われるキノコが混入してい た。

ついでマウス（ddY 系, 雄, 約 $20 \mathrm{~g}$ ）を用いて毒
性実験を行った。原因となったキノコのメタノール 抽出エキス ( $5 \mathrm{~g}$ 相当量) の腹腔内投与によって調 べた結果，ウラベニホテイシメジでは毒性を示さな かったが，クサウラベニタケと思われるキノコは 5 一6分でマウスが死亡した。

呈色反応によるキノコの鑑別 ${ }^{4)}$ 結果では，ウラベ ニホテイシメジはグアヤクチンキで反応なく，硫酸 バニリン溶液で赤紫色となった。しかしクサウラベ 
ニタケと思われるキノコは，クサウラベニタケ特有 の呈色反応を示さず同定できなかった．

そこで等電点電気泳動法を適用した結果, Fig. 6 に示したとおり両キノコは明らかに異なった泳動パ ターンを示した。クサウラベニタケは酸性側の pI 3.80 とアルカリ性側の pI 8.65，9.00 に特徵的な 蛋白質バンドがあり, 更に $\mathrm{pI} 4-6$ のバンドも異 なっており，ウラベニホテイシメジと明確に判別で きた。

以上により，呈色試験では明確な判別はできな かったものの, 形態学的判別, 毒性実験及び等電点 電気泳動法による判別結果より, 今回の食中毒事例 はウラベニホテイシメジに混入していたクサウラベ ニタケが原因であったと判断された。なお，クサウ ラベニタケ及びウラベニホテイシメジの蛋白質バン ドについて数值化した值を Table II に示した.

\section{ま と め}

有毒魚等の判別に有効であった等電点電気泳動法 をキノコ種の判別に応用し, キノコ類（採取後, 凍 結保存したもの）の水溶性蛋白質の等電点電気泳動 パターンを数値化してキノコ種を判別することを試 みた。

3 種の毒キノコの傘部分について等電点電気泳動 パターンをみたところ，明確な種特異性が認められ
た。またそれぞれのキノコについて傘部分と茎部分 の等電点電気泳動パターンを比較したところ, 荎で 一部の蛋白質バンドがうすくなるものの金と茎では ほぼ同等の泳動パターンであり，どちらを用いても 種判別が可能であった。

アカモミタケを用いて同一種内における等電点電 気泳動パターンの個体差を見たところ, pI 4.5-6.5 の範囲でそれぞれの蛋白質バンドが共通にみられ， これらの蛋白質バンドとの照合により，アカモミタ ケとしての同定が可能であった。

ドクッルタケを用いて水溶性蛋白質の加熱変性に よる等電点電気泳動パターンの変化をみたところ, $60^{\circ} \mathrm{C}$ 以上で蛋白質バンド数が急激に減少し, 高温で は 2 本程度となった。

36 種のキノコについて等電点電気泳動パターン の pI と R.P.H. (relative peak height) について数 值化を行ったところ，それぞれのキノコ種について 種特異性が認められ，数值化表を用いることにより， これらのキノコ種の判別が可能なことが示唆され た.

クサウラベニタケによる食中毒事例に等電点電気 泳動法を応用したところ，外部形態のよく似たウラ ベニホテイシメジと明確に判別でき, 食中毒原因キ ノコを特定できた。

\section{引用文 献}

1）今関六也，本郷次雄，“原色日本菌類困鑑，”保育社，大阪，1957， p. 1 .

2）今関六也，“野外ハンドブック・3，きのこ，”山と渓谷社，東京，1982，pp.239-241.

3）今関六也，本郷次雄，“原色日本菌類図鑑，”保育社，大阪，1957，pp.152-159.

4）大木正行, 吉川 進, 三浦則夫, 山浦由郎, 食品衛生研究, 36, 95 (1986).

5）今関六也, “山の幸,”山と渓谷社, 東京, 1983, p.202。

6）今関六也，本郷次雄，“原色日本菌類図鑑，”保育社，大阪，1978，pp.186-198.

7）今関六也, “野外ハンドブック・3, きのこ, ”山と溪谷社, 東京, 1982, pp.223-230.

8）落合芳博, 渡部終五, 橋本周久, 成田弘子, 浮島美之, 奈良正人, 日水誌, 50, 721 (1984).

9）浮島美之, 成田弘子, 增井俊夫, 奈良正人, 衛生化学, 30, 189 (1984).

10）浮島美之, 成田弘子, 増井俊夫, 松原壮六郎, 岡田昌二, 衛生化学, 32, 176 (1986). 